\title{
Length and time scales of atmospheric moisture recycling
}

\author{
R. J. van der Ent and H. H. G. Savenije \\ Department of Water Management, Faculty of Civil Engineering and Geosciences, Delft University of Technology, \\ Delft, The Netherlands
}

Received: 18 August 2010 - Published in Atmos. Chem. Phys. Discuss.: 20 September 2010

Revised: 1 February 2011 - Accepted: 22 February 2011 - Published: 1 March 2011

\begin{abstract}
It is difficult to quantify the degree to which terrestrial evaporation supports the occurrence of precipitation within a certain study region (i.e. regional moisture recycling) due to the scale- and shape-dependence of regional moisture recycling ratios. In this paper we present a novel approach to quantify the spatial and temporal scale of moisture recycling, independent of the size and shape of the region under study. In contrast to previous studies, which essentially used curve fitting, the scaling laws presented by us follow directly from the process equation. thus allowing a fair comparison between regions and seasons. The calculation is based on ERA-Interim reanalysis data for the period 1999 to 2008. It is shown that in the tropics or in mountainous terrain the length scale of recycling can be as low as 500 to $2000 \mathrm{~km}$. In temperate climates the length scale is typically between 3000 to $5000 \mathrm{~km}$ whereas it amounts to more than $7000 \mathrm{~km}$ in desert areas. The time scale of recycling ranges from 3 to 20 days, with the exception of deserts, where it is much longer. The most distinct seasonal differences can be observed over the Northern Hemisphere: in winter, moisture recycling is insignificant, whereas in summer it plays a major role in the climate. The length and time scales of atmospheric moisture recycling can be useful metrics to quantify local climatic effects of land use change.
\end{abstract}

\section{Introduction}

Humans are known to change evaporation through land use and water management (e.g., Gordon et al., 2008). In addition, water resources are becoming more and more stressed (e.g., Rockström et al., 2009). In this light it is important for water managers to know where the rain comes from and

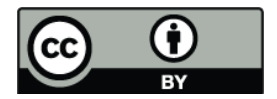

Correspondence to: R. J. van der Ent (r.j.vanderent@tudelft.nl) what happens to the moisture after it has evaporated (e.g., Yoshimura et al., 2004; Stohl and James, 2005; Bosilovich and Chern, 2006; Nieto et al., 2008; Dirmeyer et al., 2009; Van der Ent et al., 2010).

Land use and land cover changes sometimes play a major role in regional climate (e.g., Pielke Sr. et al., 2007). In fact, many types of land-atmosphere feedback exist that influence precipitation (moisture exchange, energy partitioning, particle emissions, etc.). Several studies focused on the sensitivity of precipitation to soil moisture variations (e.g., Findell and Eltahir, 1997; Koster et al., 2004; Dirmeyer et al., 2006; Kunstmann and Jung, 2007) implicitly taken into account various feedbacks mechanisms. Unfortunately, these studies generally result in model-based statistics about the strength of land-atmosphere coupling that is often hard to interpret.

This paper presents a different approach whereby we focus on the feedback of water mass (i.e. moisture) to the atmosphere. This approach allows the definition of physically meaningful and easy-to-interpret metrics that quantify land-atmosphere coupling through moisture feedback. In this perspective, a widely used metric (e.g., Brubaker et al., 1993; Eltahir and Bras, 1996; Schär et al., 1999; Burde and Zangvil, 2001; Mohamed et al., 2005; Dominguez et al., 2006; Dirmeyer and Brubaker, 2007; Kunstmann and Jung, 2007; Bisselink and Dolman, 2008) is what in this study is termed the regional precipitation recycling ratio: the ratio of regionally recycled precipitation to total precipitation in a region (see Eq. 1). A disadvantage of this metric is that its magnitude depends on the scale and shape of the region under study. As a result, it remains difficult to compare and classify regions accordingly.

The aim of this research is to derive and present scale- and shape-independent metrics that quantify land-atmosphere coupling through moisture feedback. In contrast to the scale- and shape-dependent regional precipitation recycling ratio, these newly derived metrics should allow for a fair

Published by Copernicus Publications on behalf of the European Geosciences Union. 
Table 1. The relationship between scale and precipitation recycling ratio, as found by several authors. Note that the first four studies give an areal average estimate of the recycling ratio, whereas the last gives an estimate for the recycling in a point depending on the recycling distance $x$ before that point.

\begin{tabular}{|c|c|c|c|c|c|}
\hline Study & $\begin{array}{l}\text { Formula for } \rho_{\mathrm{r}}[-] \text {, } \\
\text { with } X \text { in } \mathrm{km} \text {, } \\
\text { and } A \text { in } \mathrm{km}^{2}\end{array}$ & $\begin{array}{l}\text { Derived for range } \\
\text { (linear scale } X \\
\text { or area size } A \text { ) }\end{array}$ & $\begin{array}{l}\text { Study } \\
\text { region }\end{array}$ & Period & Method \\
\hline $\begin{array}{l}\text { (Eltahir and Bras, } \\
\text { 1994, 1996) }\end{array}$ & $0.0056 X^{0.5}$ & $X: 250-2500 \mathrm{~km}$ & Amazon & $\begin{array}{l}1985- \\
1990\end{array}$ & $\begin{array}{l}\text { Eltahir and Bras } \\
\text { bulk recycling model }\end{array}$ \\
\hline $\begin{array}{l}\text { (Dominguez } \\
\text { et al., 2006) }\end{array}$ & $\begin{array}{l}0.0573 \ln (A / 1000) \\
-0.2748\end{array}$ & $\begin{array}{l}2.5 \times 10^{4}- \\
4 \times 10^{6} \mathrm{~km}^{2}\end{array}$ & $\begin{array}{l}\text { Contiguous } \\
\text { United States }\end{array}$ & $\begin{array}{l}1979- \\
2000\end{array}$ & $\begin{array}{l}\text { Dynamic recycling } \\
\text { model }\end{array}$ \\
\hline $\begin{array}{l}\text { (Dirmeyer and } \\
\text { Brubaker, 2007) } \\
\text { (Dirmeyer et al., } \\
2009)^{\mathrm{c}}\end{array}$ & $0.000440 A^{0.457}$ & $\begin{array}{l}A: 10^{4}-10^{6} \mathrm{~km}^{2} \\
A: 10^{3}- \\
3.5 \times 10^{7} \mathrm{~km}^{2}\end{array}$ & $\begin{array}{l}\text { Global } \\
\text { (continental } \\
\text { areas only) }\end{array}$ & $\begin{array}{l}1979- \\
2004\end{array}$ & $\begin{array}{l}\text { Quasi-isentropic } \\
\text { back-trajectory } \\
\text { analysis }\end{array}$ \\
\hline \multirow[t]{2}{*}{$\begin{array}{l}\text { (Bisselink and } \\
\text { Dolman, 2008) }\end{array}$} & $\sim \operatorname{logarithm}$ of $A$ & $\begin{array}{l}A: 1.5 \times 10^{5}- \\
5 \times 10^{6} \mathrm{~km}^{2}\end{array}$ & $\begin{array}{l}\text { Central } \\
\text { Europe }\end{array}$ & $\begin{array}{l}1979- \\
2001\end{array}$ & $\begin{array}{l}\text { Dynamic recycling } \\
\text { model }\end{array}$ \\
\hline & $\begin{array}{l}\text { Formula for } \rho(x)[-] \text {, } \\
\text { with } x \text { in } \mathrm{km}\end{array}$ & $\begin{array}{l}\text { Derived for } \\
\text { distance } x\end{array}$ & & & \\
\hline $\begin{array}{l}\text { (Savenije, } \\
\text { 1995, 1996) }\end{array}$ & $1-\exp (-x / 306)$ & $x: 0-1000 \mathrm{~km}$ & $\begin{array}{l}\text { West Africa to } \\
\text { Southern Sahel }\end{array}$ & $\begin{array}{l}1951- \\
1990\end{array}$ & $\begin{array}{l}\text { Savenije analytical } \\
\text { recycling model }\end{array}$ \\
\hline
\end{tabular}

a This formula is an average of monthly averages (Dominguez et al., 2006, Fig. 8). Dominguez et al. (2006) also present a formula for the months June, July and August only. It should be noted that this formula is the result of curve fitting, and that it is thus not based on their own process equation (Dominguez et al., 2006, Eq. 20) ${ }^{2}$ This is the global formula taken from Dirmeyer and Brubaker (2007, Table 1). They present additional formulas for individual regions. ${ }^{\mathrm{c}}$ Note that on the basis of Dirmeyer and Brubaker (2007, Fig. 3) we can estimate their global formula to be different: $\rho_{\mathrm{r}}=0.0003 A^{0.457}$, and in the work of Dirmeyer et al. $\left(2009\right.$, Fig. 3) we can estimate it to be: $\rho_{\mathrm{r}}=0.00035 A^{0.457}$. Fortunately, this inconsistency does not matter when scaling regional recycling ratios, because for that only the value of the exponent (0.457) is of interest. ${ }^{\mathrm{d}}$ No formula given (see Bisselink and Dolman, 2008, Fig. 4). ${ }^{\text {e }}$ This formula is not given explicitly, but obtained after filling in the parameters that were calibrated in the work of Savenije (1995, p. 70).

comparison among regions and seasons. To that effect we have derived the spatial and temporal scales of moisture recycling. First in Sect. 2 the scale- and shape-dependence of regional moisture recycling will be explained. Subsequently, a new spatial metric (length scale) and the associated temporal metric (time scale) will be derived. In Sect. 3 the results obtained by this approach (length and time scales of moisture recycling) are presented and discussed by continent, distinguishing between yearly average, summer and winter conditions. Finally, Sect. 4 presents some concluding remarks on the significance of the results obtained.

\section{Methods}

\subsection{Scale- and shape-dependence of regional moisture recycling}

In a previous study we presented definitions for different types of moisture recycling (Van der Ent et al., 2010). The regional precipitation recycling ratio $\rho_{\mathrm{r}}$ was defined as:

$$
\begin{aligned}
& \rho_{\mathrm{r}}(t, x, y \mid A, \varsigma)=\frac{P_{\mathrm{r}}(t, x, y \mid A, \varsigma)}{P_{\mathrm{r}}(t, x, y \mid A, \varsigma)+P_{\mathrm{a}}(t, x, y \mid A, \varsigma)} \\
& =\frac{P_{\mathrm{r}}(t, x, y \mid A, \varsigma)}{P(t, x, y \mid A, \varsigma)}
\end{aligned}
$$

Where $P_{\mathrm{r}}$ is regionally recycled precipitation, $P_{\mathrm{a}}$ is precipitation that originates from moisture that was brought into the region by advection, and $P$ is total precipitation. All variables depend on time $t$ and location of the region $(x, y)$, given an area size $A$ and shape $\zeta$. This ratio describes the region's dependence on evaporation from within the region to sustain precipitation in that same region. Van der Ent et al. (2010) also defined the reverse process: the fraction of the evaporated water that returns as precipitation in the same region. This is the regional evaporation recycling ratio $\varepsilon_{\mathrm{r}}$ :

$$
\begin{aligned}
& \varepsilon_{\mathrm{r}}(t, x, y \mid A, \varsigma)=\frac{E_{\mathrm{r}}(t, x, y \mid A, \varsigma)}{E_{\mathrm{a}}(t, x, y \mid A, \varsigma)+E_{\mathrm{r}}(t, x, y \mid A, \varsigma)} \\
& =\frac{E_{\mathrm{r}}(t, x, y \mid A, \varsigma)}{E(t, x, y \mid A, \varsigma)}
\end{aligned}
$$

where $E_{\mathrm{r}}$ is the part of the evaporation from the region which returns as precipitation to the same region, and $E_{\mathrm{a}}$ is evaporated water that is advected out of the region. Averaged over 
Continental precipiation recycling ratio $\rho_{c}$

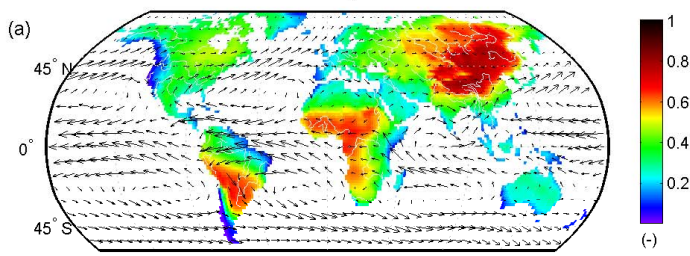

Continental evaporation recycling ratio $\varepsilon_{c}$

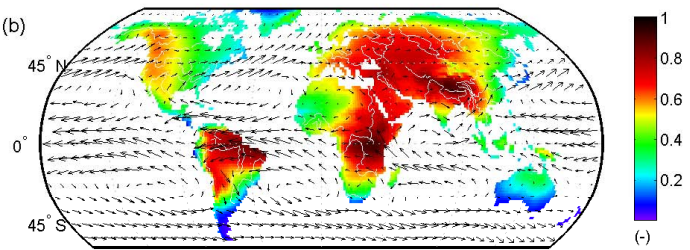

Fig. 1. Average continental moisture recycling ratios (1999-2008): (a) continental precipitation recycling ratio $\rho_{\mathrm{c}}$ (Eq. 4) and (b) continental evaporation recycling ratio $\varepsilon_{\mathrm{c}}$ (Eq. 5). The arrows indicate the horizontal moisture flux field. Figure modified from Van der Ent et al. (2010).

a year $E_{\mathrm{r}}$ equals $P_{\mathrm{r}}$ (assuming no substantial change in atmospheric moisture storage over a year) and hence:

$E_{\mathrm{r}}($ year, $x, y \mid A, \varsigma)=P_{\mathrm{r}}($ year, $x, y \mid A, \varsigma)$

Comparing regional recycling ratios from different regions and authors has proven to be difficult because of their scaledependence. Several studies tried to find a relation between the regional precipitation recycling ratio and region scale (see Table 1). We observe that the formulas presented in the upper part of Table 1 may be justifiable for the spatial range for which they have been derived, but that none of them holds in their limit of applicability, i.e. the very nature of $\rho_{\mathrm{r}}$ requires it to vary between 0 (in a point) and 1 (whole Earth). Moreover, the formulas in Table 1 have the drawback that their coefficients are not dimensionless.

In a global study one typically has grid cells of a fixed latitude and longitude; such grid cells are smaller at higher latitudes. In order to compare the strength of land-atmosphere feedback in different regions, Dirmeyer and Brubaker (2007) use the global exponent (0.457) of their exponential function (see Table 1) to scale regional precipitation recycling ratios of different grid cells to a common reference area $\left(10^{5} \mathrm{~km}^{2}\right)$. Dirmeyer et al. (2009) use the same approach to scale precipitation recycling in countries to a common reference area. Dirmeyer and Brubaker (2007, Table 1) also showed that there is in fact a significant spread in the value of the exponent per region, which highlights one of the drawbacks of this approach. But most importantly, their approach does not take into account the effect of the orientation of the moisture flux compared to the orientation and shape of the study region (e.g. grid cell or country). This may lead to an underestimation of the regional feedback process in rectangular shaped grid cells which are oriented perpendicular to the moisture flux, and an overestimation when they are oriented in the same direction as the moisture flux.

In our previous study we used scale-independent continental moisture recycling ratios to describe the land-atmosphere feedback process at continental scale (Van der Ent et al., 2010). We defined the continental precipitation recycling ratio $\rho_{\mathrm{c}}$ as:

$\rho_{\mathrm{c}}(t, x, y)=\frac{P_{\mathrm{c}}(t, x, y)}{P_{\mathrm{o}}(t, x, y)+P_{\mathrm{c}}(t, x, y)}=\frac{P_{\mathrm{c}}(t, x, y)}{P(t, x, y)}$ where $P_{\mathrm{c}}$ denotes precipitation which has continental origin (i.e. most recently evaporated from any continental area), and $P_{\mathrm{o}}$ is precipitation which has oceanic origin (i.e. most recently evaporated from the ocean). Also, we defined the continental evaporation recycling ratio $\varepsilon_{\mathrm{c}}$ as:

$\varepsilon_{\mathrm{c}}(t, x, y)=\frac{E_{\mathrm{c}}(t, x, y)}{E_{\mathrm{o}}(t, x, y)+E_{\mathrm{c}}(t, x, y)}=\frac{E_{\mathrm{c}}(t, x, y)}{E(t, x, y)}$

where $E_{\mathrm{c}}$ is terrestrial evaporation that returns as continental precipitation, $E_{\mathrm{o}}$ is terrestrial evaporation that precipitates on an ocean and $E$ is total evaporation. We found for example that recycling over the Eurasian continent is the main source of China's water resources and that evaporation from the Amazon region sustains precipitation in the Río de la Plata basin (Fig. 1). We also identified hotspots of regional recycling where both $\rho_{\mathrm{c}}$ and $\varepsilon_{\mathrm{c}}$ are high, such as the area just east of the Andes and the Tibetan Plateau. However, in this paper we try to find directly interpretable spatial and temporal metrics for local moisture feedback, which will turn out to be more consistent than those following from the scaling equations presented in Table 1 .

\subsection{Spatial scale for local precipitation-evaporation feedback}

In order to derive a new spatial measure we start from the assumption that the atmospheric moisture follows a certain streamline over which it interacts with the land surface. The process equation describing the relationship between precipitation recycling and distance travelled along an atmospheric streamline was derived by Dominguez et al. (2006, Eq. 20), which in our symbols reads:

$\rho(x)=1-\left(\exp \left(-\frac{E}{S_{a} u} x\right)\right), \quad$ with $x \geq 0$

Where, $\rho$ is the precipitation recycling ratio, $E$ is evaporation, $S_{a}$ is atmospheric moisture storage (i.e. precipitable water), $u$ is horizontal wind speed and $x$ is the distance along a streamline (starting in $x=0$ ), whereby $E, S a$ and $u$ vary in time and space. These latter variables can be grouped into one simple and meaningful metric $\lambda_{\rho}=\frac{S_{a} u}{E}$, which leads to the following equation:

$\rho(x)=1-\exp \left(-\frac{x}{\lambda_{\rho}}\right), \quad$ with $x \geq 0$ 

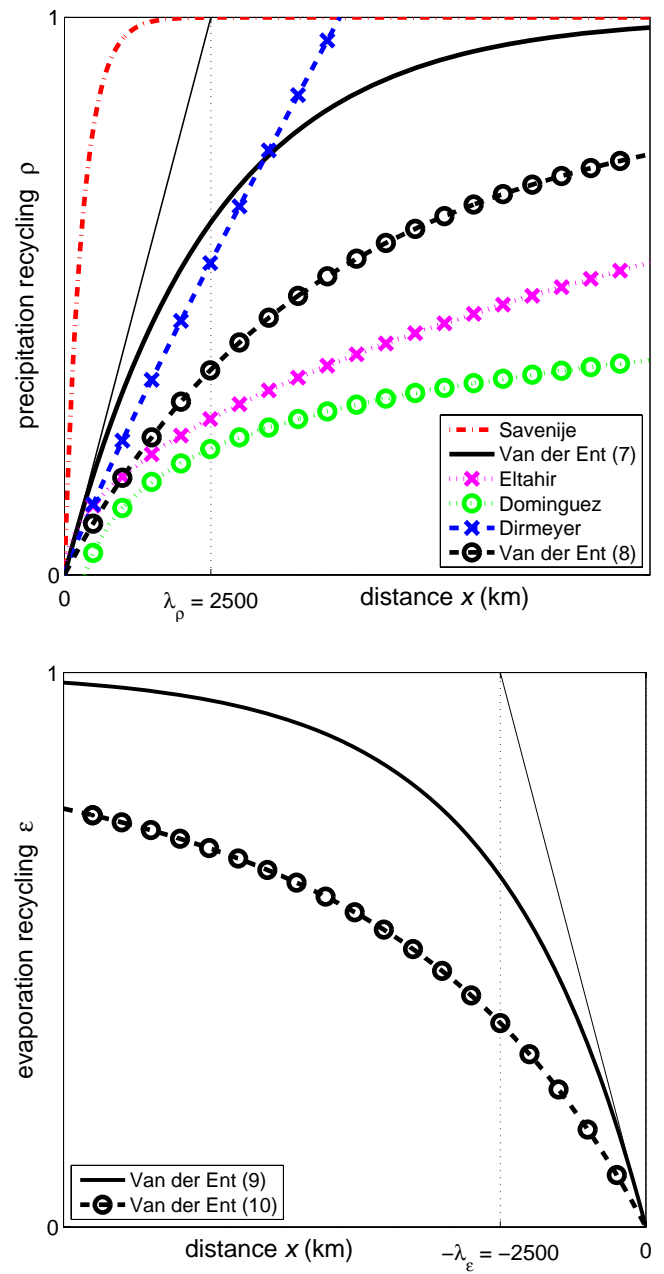

Fig. 2. The relationship between recycling ratios and distance using different formulas (see Table 1). The formula of Savenije (1995) and Eqs. (7) and (9) are defined in a point $x$, while the other formulas are defined as an areal average recycling ratio. Note that in the formulas of Dominguez et al. (2006) and Dirmeyer and Brubaker (2007) the area $A$ was replaced by $X^{2}$, thus we assumed a square region. The results displayed here are meant to highlight different formula behavior, not to compare magnitudes, since all have parameters that were calibrated for different regions.

Where $\lambda_{\rho}$ is the length scale of the precipitation recycling. Note that $\rho$ is defined in a point $x$ and not as an areal average. We also want to obtain the average precipitation recycling ratio over a distance (i.e. the regional precipitation recycling ratio $\rho_{\mathrm{r}}$ (Eq. 1). Therefore, we integrate Eq. (7), fill in the boundary condition $\rho_{\mathrm{r}}=0$ if $x=0$, and divide by $x$, yielding:

$\rho_{\mathrm{r}}=\frac{x+\lambda_{\rho} \exp \left(-\frac{x}{\lambda_{\rho}}\right)-\lambda_{\rho}}{x}, \quad$ with $x \geq 0$

Equations (7) and (8) both satisfy the condition that $\rho=0$ if $x=0$, and $\rho=1$ if $x=\infty$, independent of the length scale $\lambda_{\rho}$. The formulation for the evaporation recycling ratio $\varepsilon$ is simi- lar; for $x=0$ it must hold that $\varepsilon=0$, and $\varepsilon=1$ if $x=-\infty$, yielding:

$\varepsilon(x)=1-\exp \left(\frac{x}{\lambda_{\varepsilon}}\right), \quad$ with $x \leq 0$

Where $x$ is the distance along a streamline (ending at $x=0$ ), $\lambda_{\varepsilon}$ is the length scale of the evaporation recycling. It can be seen that $\varepsilon$ depends on the distance that moisture still has to travel until point $x=0$, while $\rho$ depends on the distance that was already travelled by the moisture. The average evaporation recycling ratio over a distance (i.e. the regional evaporation recycling ratio $\varepsilon_{\mathrm{r}}$, Eq. 2) can be obtained by:

$\varepsilon_{\mathrm{r}}=\frac{x-\lambda_{\varepsilon} \exp \left(\frac{x}{\lambda_{\varepsilon}}\right)+\lambda_{\varepsilon}}{x}, \quad x \leq 0$

Figure 2 shows how the new formulations (Eqs. 7-10) behave compared to formulations found by other studies if we assume recycling with a length scale $\lambda$ of $2500 \mathrm{~km}$.

\subsection{Calculating the length scale of moisture feedback}

Suppose that the regional moisture recycling ratio over a trajectory $\Delta x$ is known, then it is possible to calculate the corresponding length scale of moisture recycling. First, we write the general formula for the moisture recycling ratio in a point:

$\gamma(|x|)=1-\exp \left(-\frac{|x|}{\lambda_{\gamma}}\right)$

Where $\gamma$ can be replaced by either $\rho$ (where $x \geq 0$ ) or $\varepsilon$ (where $x \leq 0$ ). The general formula for the regional moisture recycling ratio $\gamma_{\mathrm{r}}$ over a trajectory $\Delta x$ then follows from integration of Eq. (11) between 0 and $|x|$, divided by $\Delta x$ :

$\gamma_{\mathrm{r}}=\frac{\Delta x+\lambda_{\gamma} \exp \left(-\frac{\Delta x}{\lambda_{\gamma}}\right)-\lambda_{\gamma}}{\Delta x}$

If we assume a linear approximation of $\gamma(|x|)$ through the origin in Eq. (11), for small values of $|x|$, then $\gamma_{\mathrm{r}} \approx \gamma / 2$. Substituting this in Eq. (11) and solving for $\lambda_{\gamma}$ yields:

$\lambda_{\gamma} \approx-\frac{\Delta x}{\ln \left(1-2 \gamma_{\mathrm{r}}\right)}$

Using WolframAlpha we obtained an exact solution of Eq. (12) for $\lambda_{\gamma}$ :

$\lambda_{\gamma}=\frac{\Delta x}{\mathbf{W}\left(\frac{\exp \left(\frac{1}{\gamma_{\mathrm{r}}-1}\right)}{\gamma_{\mathrm{r}}-1}\right)+\frac{1}{1-\gamma_{\mathrm{r}}}}$

Where, $\mathbf{W}(z)$ is the Lambert W-Function (e.g., Corless et al., 1996), which is defined as the function $\mathbf{W}(z)$ that satisfies:

$\mathbf{W}(z) \exp (\mathbf{W}(z))=z$ 

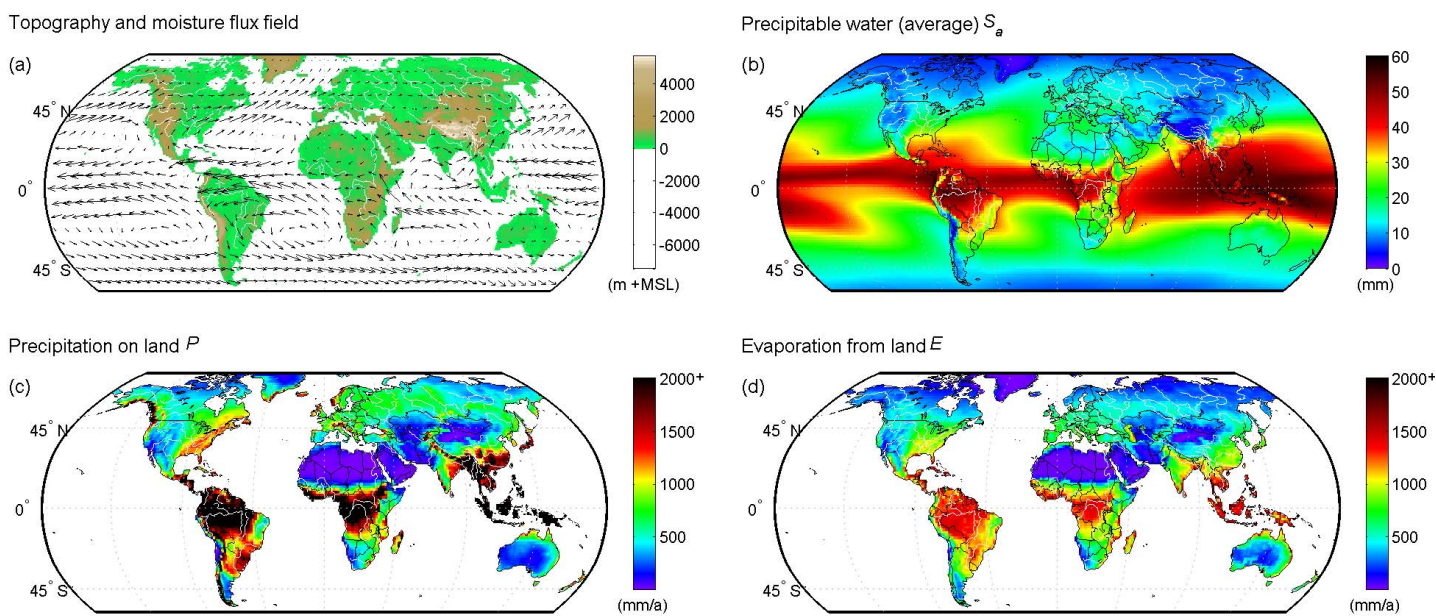

Fig. 3. Climatology of the study area taken from the ERA-Interim reanalysis (1999-2008): (a) topography and horizontal (vertically integrated) moisture flux field (indicated by arrows), (b) average atmospheric moisture storage (i.e. precipitable water) $S_{\mathrm{a}}$, (c) precipitation on land $P$, and (d) evaporation from land $E$. Parts of the figure (a, c and d) modified from Van der Ent et al. (2010).

Note that in Eqs. (13) and (14) the length scale $\lambda_{\gamma}$ depends on the regional moisture recycling ratio $\gamma_{\mathrm{r}}$ over a trajectory $\Delta x$, while it is more conventional that the ratio is calculated for a grid cells with area size $A$ (e.g., Dirmeyer and Brubaker, 2007; Van der Ent et al., 2010). This discrepancy can be overcome by calculating a representative length of the grid cell; it is the zonal plus the meridional length of the grid cell both weighted by ratio of moisture fluxes in that direction divided by the total horizontal (vertically integrated) moisture flux:

$\Delta x=L_{\mathrm{Z}} \frac{F_{\mathrm{Z}}}{F_{\mathrm{Z}}+F_{\mathrm{M}}}+L_{\mathrm{M}} \frac{F_{\mathrm{M}}}{F_{\mathrm{Z}}+F_{\mathrm{M}}}$

Where $L_{Z}$ is the length of a grid cell in zonal direction, $L_{\mathrm{M}}$ is the length of a grid cell in meridional direction, $F_{\mathrm{Z}}$ is the moisture flux in zonal direction, and $F_{M}$ is the moisture flux in meridional direction. In conclusion, it should be noted that the methodology presented here follows directly from the process equations, while other studies essentially used curve fitting (top half of Table 1).

\subsection{Time scale of moisture feedback}

Besides the length scales of precipitation-evaporation interactions we are also interested in its time scales. Trenberth (1998) offers an approach to calculate these time scales; he defines the depletion time of atmospheric moisture $T_{\mathrm{P}}$ as (using our symbols):

$T_{\mathrm{P}}=\overline{S_{\mathrm{a}}} / P$

Where $S_{\mathrm{a}}$ is atmospheric moisture storage (i.e. precipitable water). Similarly, Trenberth (1998) defines the restoration time, which we prefer to term the replenishment time of atmospheric moisture $T_{\mathrm{E}}$ as:

$T_{\mathrm{E}}=\overline{S_{\mathrm{a}}} / E$
When both replenishment time $T_{\mathrm{E}}$ and depletion time $T_{\mathrm{P}}$ in a region are small one would expect high regional moisture recycling, but this obviously also depends on the horizontal atmospheric moisture fluxes coming in and out of a region. Note that both $T_{\mathrm{E}}$ and $T_{\mathrm{P}}$ (Eqs. 17 and 18) are local timescales for precipitation and evaporation, which give an indication for the residence time of atmospheric moisture if horizontal moisture transport is small. Actual residence time should be calculated by taking a Langrangean approach (Bosilovich et al., 2002). However, that does not yield local metrics, which is the objective of this paper.

\subsection{Data}

The meteorological input data are taken from the ERAInterim reanalysis (Berrisford et al., 2009). We have used precipitation and evaporation ( $3 \mathrm{~h}$ intervals), and additionally: specific humidity, zonal and meridional wind speed at the lowest 24 pressure levels $(175-1000 \mathrm{hPa})$, and surface pressure $(6 \mathrm{~h}$ intervals) in order to calculate the horizontal (vertically integrated) moisture fluxes and precipitable water (see Fig. 3). All data are available at a $1.5^{\circ}$ latitude $\times 1.5^{\circ}$ longitude grid. The data used cover the period of 1999 to 2008. We refer to our previous study for further details (Van der Ent et al., 2010).

Moreover, we have used regional moisture recycling ratios within a grid cell, as calculated by Van der Ent et al. (2010) (see Fig. 4a, b). The water accounting model, which underlies these calculations was described in our previous work (Van der Ent et al., 2010). We downscaled the reanalysis data set to $0.5 \mathrm{~h}$ resolution to reduce the Courant number. The most important simplification in this model is probably the assumption of a well-mixed atmosphere (see e.g., Burde and Zangvil, 2001; Burde, 2006; Fitzmaurice, 2007). However, 

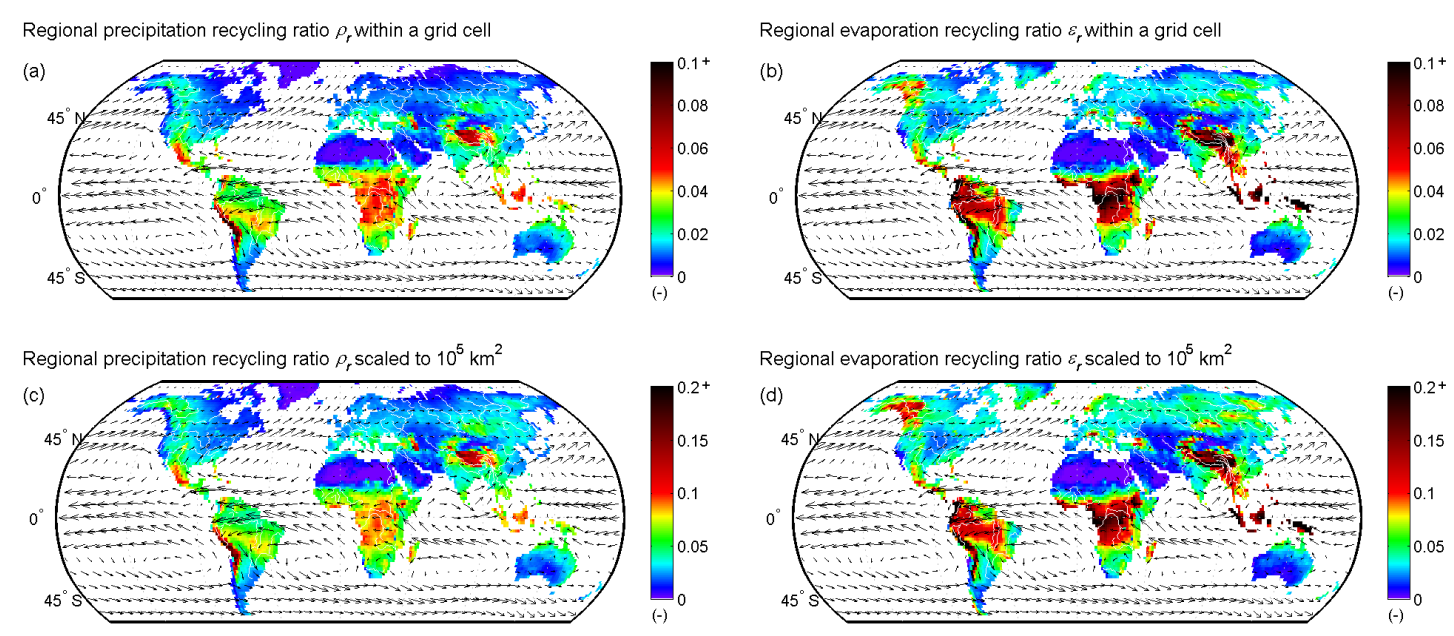

Fig. 4. Average regional moisture recycling ratios (1999-2008): (a) regional precipitation recycling ratio $\rho_{\mathrm{r}}$ within a $1.5^{\circ} \times 1.5^{\circ}$ grid cell, (b) regional evaporation recycling ratio $\varepsilon_{\mathrm{r}}$ within a $1.5^{\circ} \times 1.5^{\circ}$ grid cell, (c) regional precipitation recycling ratio $\rho_{\mathrm{r}}$ scaled to a reference area of $10^{5} \mathrm{~km}^{2}$, and (d) regional evaporation recycling ratio $\varepsilon_{\mathrm{r}}$ scaled to a reference area of $10^{5} \mathrm{~km}^{2}$. The arrows indicate the horizontal moisture flux field. Parts of the figure (a and b) modified from Van der Ent et al. (2010).

the results of Van der Ent et al. (2010) were shown to correspond well with water vapor tracer studies that did not invoke the well-mixed assumption (e.g., Bosilovich and Chern, 2006; Bosilovich et al., 2002), and therefore we believe that this assumption will not significantly affect the results presented in this paper.

However, it should be noted that the results presented hereafter are (just like in any other study) limited by the validity of the input data. Reanalysis data is known to have an imbalance in its water budget, mostly affecting precipitation and evaporation. In Van der Ent et al. (2010) we provided a global comparison of ERA-Interim's water budget with other global estimates (Oki and Kanae, 2006; Trenberth et al., 2007) from which we found that ERA-Interim has slightly higher estimates of precipitation and evaporation. This might in general lead to slight underestimation of the recycling length scales and depletion and replenishment times, although locally it may be the opposite.

\section{Results and discussion}

\subsection{Length and time scales of moisture feedback}

Figure $4 \mathrm{a}, \mathrm{b}$ shows the annual average regional moisture recycling ratios $\left(\rho_{\mathrm{r}}\right.$ and $\left.\varepsilon_{\mathrm{r}}\right)$ on the $1.5^{\circ}$ latitude $\times 1.5^{\circ}$ longitude grid. Following the approach of Dirmeyer and Brubaker (2007) we have scaled these ratios with an exponent (0.457) to a common reference area of $10^{5} \mathrm{~km}^{2}$ (Fig. $4 \mathrm{c}, \mathrm{d}$ ). We see that on higher latitudes new regions of high regional recycling pop up. However, as mentioned before, this scaling approach does not take into account the orientation of the moisture flux compared to the shape of a region.
Figure 5 shows the annual average length scales of moisture recycling $\left(\lambda_{\rho}\right.$ and $\left.\lambda_{\varepsilon}\right)$ calculated with Eq. (14). We like to emphasize that these length scales are local scaleindependent characteristics. They are process scales: the inverse value of $\lambda$ represents the spatial gradient of the recycling process and $\lambda$ itself is a length scale of the spatial variability of moisture recycling. Note, that these process scales are different from actual travel distances (e.g., Sodemann et al., 2008). However, the length scales $\lambda_{\rho}$ and $\lambda_{\varepsilon}$ can be interpreted as the mean distance a water particle travels under local hydrological and climatological conditions. This is analogous to e.g. human travel, where someone's local speed can differ significantly from his average speed. Furthermore, it should be noted that a smaller length scale indicates a higher feedback strength, since this means that there is more recycling of moisture (see Eqs. 6, 7 and 11). As a result, we believe that these length scales (Fig. 5) have more physical meaning than the scaled regional recycling ratios (Fig. 4c, d). From visual comparison the patterns in Figs. 4c, $\mathrm{d}$ and 5 appear to be similar, except at higher latitudes, where the approach of scaling (Fig. 4c, d) is weak.

Therefore, we have made a numerical comparison in Table 2 between different metrics for moisture feedback for two differently shaped grid cells (one in North-West Canada and one in the Amazon). If one would look at the $\rho_{\mathrm{r}}$ within a $1.5^{\circ} \times 1.5^{\circ}$ grid cell one would conclude that the local feedback strength is higher in the Amazon grid cell. Next, taking into account the difference in grid size, and thus scaling $\rho_{\mathrm{r}}$ following the approach of Dirmeyer and Brubaker (2007), one would consider the local feedback strength to be about the same. However, taking into account also the orientation of the moisture flux compared to the shape of the grid cell, we can observe that the length scale of the precipitation 

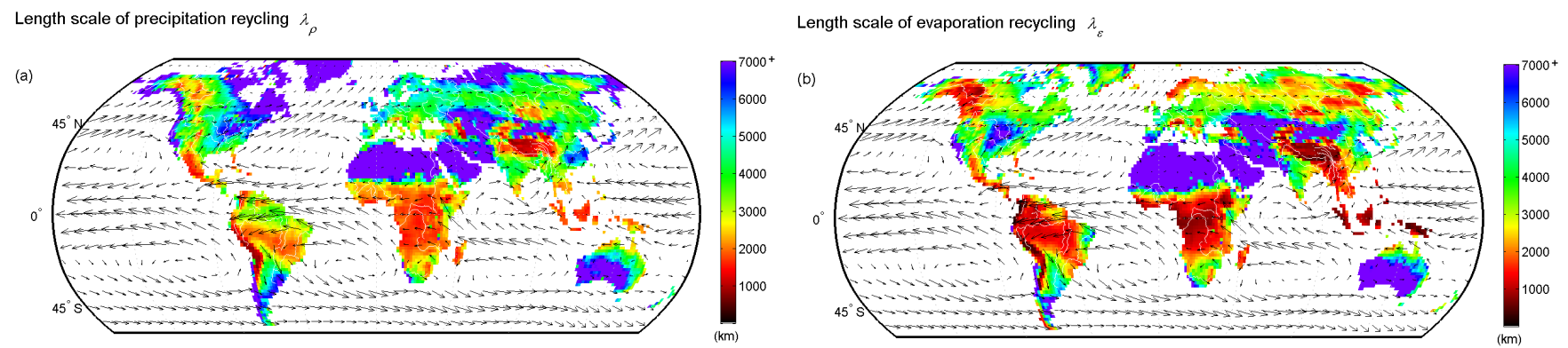

Fig. 5. Average length scales of moisture recycling (Eq. 14) (1999-2008): (a) length scale of the precipitation recycling $\lambda \rho$, and (b) length scale of the evaporation recycling $\lambda_{\varepsilon}$. These are local characteristics of feedback strength, which can be interpreted as travel distances of atmospheric water, under the local conditions of a grid cell. The arrows indicate the horizontal moisture flux field.

recycling $\lambda_{\rho}$ for the grid cell in North-West Canada is shorter than for the grid cell in the Amazon, thus indicating a higher feedback strength. The same reasoning can be followed for evaporation recycling.

To complete the picture, Fig. 6 shows the depletion and replenishment time of atmospheric moisture $\left(T_{\mathrm{P}}\right.$ and $T_{\mathrm{E}}$, Eqs. 17 and 18), computed following the approach of Trenberth (1998). Looking at Figs. 5 and 6 jointly, we can observe that the local moisture feedback strength is very heterogeneously distributed over the world. In general, the highest feedback is observed in tropical and/or mountainous regions, while the least feedback is observed in arid climate zones.

\subsection{Local moisture recycling by continent}

Looking at North America the length scale of precipitation recycling $\lambda_{\rho}$ (Fig. 5a) is typically between 1500 and $4000 \mathrm{~km}$ over the Rocky Mountains. This indicates relative high local feedback, but the average precipitable moisture $S_{\mathrm{a}}$ (Fig. 3b) is low. The windward side of the Canadian Rocky Mountains beautifully illustrates the difference between $\lambda_{\rho}$ (Fig. 5a) and $\lambda_{\varepsilon}$ (Fig. 5b): most precipitation is brought to the continent over the ocean indicated by low $\lambda_{\rho}$, but $\lambda_{\varepsilon}$ is only about $1500 \mathrm{~km}$, thus indicating a relative fast feedback of evaporated moisture. In the East of North America depletion and replenishment times $\left(T_{\mathrm{P}}\right.$ and $T_{\mathrm{E}}$, Fig. 6) remain in the same order (3-12 days) as in the West of the continent. However, local recycling plays a less dominant role and moisture is transported over greater distances (Fig. 5) indicating that horizontal moisture fluxes are greater.

In the northern part of the Amazon region, the length scale of precipitation recycling $\lambda_{\rho}$ (Fig. 5a) is about $3500 \mathrm{~km}$ but in the southern part of the Amazon region $\lambda_{\rho}$ is less than $2000 \mathrm{~km}$, indicating a less important role for convergence and a more important role for moisture recycling. The length scale of evaporation recycling $\lambda_{\varepsilon}$ is less than $2000 \mathrm{~km}$ for the whole Amazon region, and this in fact corresponds with Fig. 1a where we can observe that $70 \%$ of the precipitation in the center of the South American continent is of terrestrial
Table 2. Different measures of moisture feedback for a rectangular grid cell (in North-West Canada) an almost square grid cell (in the Amazon region). Note that a shorter length scale indicates more moisture recycling.

\begin{tabular}{|c|c|c|c|}
\hline & $\begin{array}{l}\text { Grid cell in } \\
\text { North-West } \\
\text { Canada }\end{array}$ & & $\begin{array}{l}\text { Grid cell in } \\
\text { the Amazon } \\
\text { region }\end{array}$ \\
\hline $\begin{array}{l}\text { Coordinates of the center of the } \\
\text { grid cell (latitude, } \\
\text { longitude) }\end{array}$ & $64.5^{\circ} \mathrm{N}$ & & $\begin{array}{l}6^{\circ} \mathrm{S}, 49.5^{\circ} \mathrm{W} \\
129^{\circ} \mathrm{W}\end{array}$ \\
\hline Area size grid cell $\left(\mathrm{km}^{2}\right)$ & $1.20 \times 10^{4}$ & & $2.76 \times 10^{4}$ \\
\hline Zonal length $(\mathrm{km})$ & 76 & & 165 \\
\hline Meridional length (km) & 167 & & 167 \\
\hline $\begin{array}{l}\text { Regional precipitation recycling } \\
\text { ratio } \rho_{\mathrm{r}} \text { within } \\
\text { a } 1.5^{\circ} \times 1.5^{\circ} \text { grid cell }(-)\end{array}$ & 0.017 & $<$ & 0.027 \\
\hline $\begin{array}{l}\text { Regional precipitation recycling } \\
\text { ratio } \rho_{\mathrm{r}} \text { scaled (with } \\
\text { exponent } 0.457 \text { ) to a reference } \\
\text { area of } 10^{5} \mathrm{~km}^{2}(-)\end{array}$ & 0.047 & $\approx$ & 0.049 \\
\hline $\begin{array}{l}\text { Length scale of the precipitation } \\
\text { recycling } \lambda_{\rho}(\mathrm{km})\end{array}$ & $2.4 \times 10^{3}$ & $<$ & $3.0 \times 10^{3}$ \\
\hline $\begin{array}{l}\text { Depletion time of atmospheric } \\
\text { moisture } T_{\mathrm{P}} \text { (days) }\end{array}$ & 4.2 & & 5.6 \\
\hline $\begin{array}{l}\text { Regional evaporation recycling } \\
\text { ratio } \varepsilon_{\mathrm{r}} \\
\text { within a } 1.5^{\circ} \times 1.5^{\circ} \text { grid cell }(-)\end{array}$ & 0.045 & $<$ & 0.059 \\
\hline $\begin{array}{l}\text { Regional evaporation recycling } \\
\text { ratio } \varepsilon_{\mathrm{r}} \text { scaled } \\
\text { (with exponent } 0.457 \text { ) to an area } \\
\text { of } 10^{5} \mathrm{~km}^{2}(-)\end{array}$ & 0.122 & $\approx$ & 0.108 \\
\hline $\begin{array}{l}\text { Length scale of the evaporation } \\
\text { recycling } \lambda_{\varepsilon}(\mathrm{km})\end{array}$ & $0.9 \times 10^{3}$ & $<$ & $1.3 \times 10^{3}$ \\
\hline $\begin{array}{l}\text { Replenishment time of atmo- } \\
\text { spheric moisture } T_{\mathrm{E}} \\
\text { (days) }\end{array}$ & 11.0 & & 12.3 \\
\hline
\end{tabular}



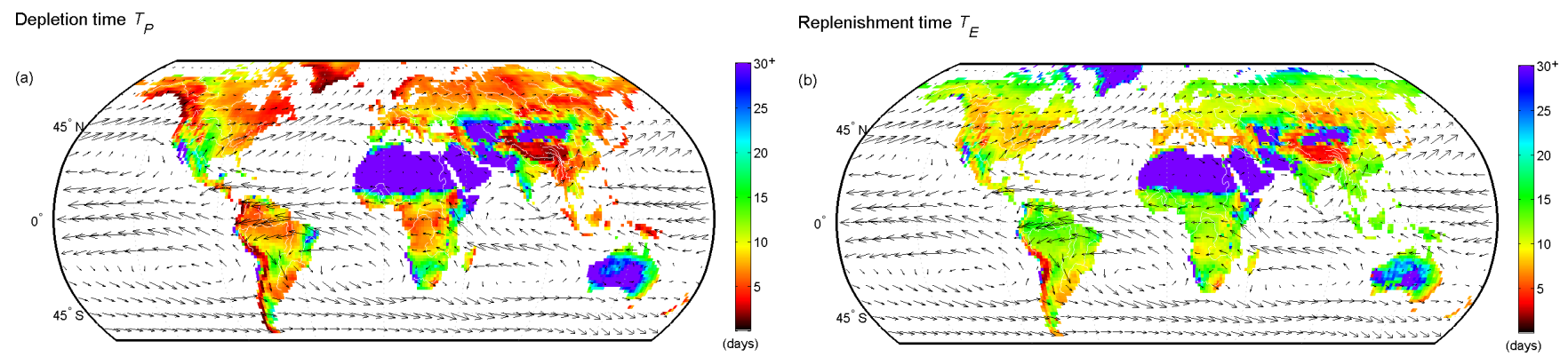

Fig. 6. Average time scales of moisture feedback (1999-2008): (a) depletion time $T_{\mathrm{P}}$ (Eq. 17), i.e. the average time it would take to completely deplete atmospheric moisture assuming precipitation to remain constant and not considering lateral fluxes, and (b) replenishment time $T_{\mathrm{E}}$ (Eq. 18), i.e. the time it takes to completely replenish atmospheric moisture by assuming evaporation to remain constant and not considering lateral fluxes. The arrows indicate the horizontal moisture flux field.

origin. Local moisture recycling is highest near the Andes mountains, which is indicated by both Figs. 5 and 6 .

In Africa we can observe two very different systems. First there is the Sahara, which basically has no water and therefore no local moisture feedback. Second, we can observe a relative strong moisture feedback over the rest of the continent, especially in the Congo basin, where the length scale of the evaporation recycling $\lambda_{\varepsilon}$ (Fig. 5b) can be as low as 500 to $1000 \mathrm{~km}$, and depletion time $T_{\mathrm{P}}$ (Fig. 6a) well below 7 days. The Congo region lacks major mountain ridges to trigger rainfall, and in this light the forests, sustaining atmospheric moisture through evaporation, are of utmost importance for the region's water resources.

The strongest feedback in Europe is observed around the Mediterranean (see Figs. 5 and 6). Furthermore, the northern part of Eurasia is characterized by a long belt wherein the length scale of precipitation recycling $\lambda_{\rho}$ (Fig. 5a) is around $4000 \mathrm{~km}$ and replenishment time $T_{\mathrm{E}}$ (Fig. 6b) around 10 days. Below that belt (the Middle East, central Asia and the Gobi desert) land-atmosphere feedback is very low and this is also reflected by small precipitation amounts (Fig. 3c) observed for these regions. Despite that depletion time $T_{\mathrm{P}}$ (Fig. 6a) in the most northern parts of Siberia is as low as 5 days. This does not necessarily reflect strong moisture feedback, since replenishment time $T_{\mathrm{E}}$ is around 15 days.

Over the Tibetan Plateau we can observe a very strong local moisture recycling, with $\lambda_{\rho}$ and $\lambda_{\varepsilon}$ (Fig. 5) around $1000 \mathrm{~km}$. This strong feedback was also found by earlier studies on the isotopic compositions of rainfall around the Tibetan Plateau (Tian et al., 2001; Yu et al., 2007; Liu et al., 2008). In India and the east of China, local moisture recycling plays again a less important role. Very strong local recycling is observed in the tropical regions of Southeast Asia where $\lambda_{\varepsilon}$ (Fig. 5b) can be well below $1000 \mathrm{~km}$. Given that total $P$ and $E$ (Fig. 3) are very high as well, there is also a high absolute feedback of moisture.
Finally, recycling of moisture is of little significance over most of Australia; the length scales $\left(\lambda_{\rho}\right.$ and $\lambda_{\varepsilon}$, Fig. 5) are over $7000 \mathrm{~km}$, and the time scales are over 30 days. Local recycling is only significant in the outer north and east of Australia as well as in New Zealand. In New Zealand the length scales $\left(\lambda_{\rho}\right.$ and $\lambda_{\varepsilon}$, Fig. 5) are around $4000 \mathrm{~km}$ while the time scales of recycling are around 7 days $\left(T_{\mathrm{P}}\right.$ and $T_{\mathrm{E}}$, Fig. 6).

\subsection{Seasonal variations}

Figures 7 and 8 show the length and time scales of moisture recycling for typical winter and summer conditions. For the calculation of the regional evaporation recycling $\varepsilon_{\mathrm{r}}$ (and thus also the length scale $\lambda_{\varepsilon}$, Figs. 7b and 8b) we did invoke the assumption that $P_{\mathrm{r}}=E_{\mathrm{r}}$, which is only true if there is no substantial change in atmospheric moisture storage. However, this is probably only fully justified on the timescale of a year (Eq. 3), so the results presented in Figs. $7 \mathrm{~b}$ and $8 \mathrm{~b}$ should be interpreted with caution.

Yet it is clear that there is considerable seasonal variation in local moisture feedback. For example, the Northern Hemisphere above $45^{\circ} \mathrm{N}$ in winter (Fig. 7) shows a depletion time of atmospheric moisture $T_{\mathrm{P}}$ (Fig. 7c) which is generally lower than 10 days, however replenishment time $T_{\mathrm{E}}$ (Fig. 7d) is over 30 days, resulting in $\lambda_{\rho}$ (Fig. 7a) being over $7000 \mathrm{~km}$. Even though $\lambda_{\varepsilon}$ (Fig. $7 \mathrm{~b}$ ) above $45^{\circ} \mathrm{N}$ indicates a relative fast feedback of evaporated moisture, total evaporation in winter is known to be low for this region. For this region, local moisture recycling can be observed to play a much more important role in July (Fig. 8). For other regions similar differences between winter and summer conditions can be observed, whereby land-atmosphere feedback is generally (and not surprisingly) greater during wet and warm periods. 
Length scale of precipitation reycling $\lambda_{\rho}$ in January

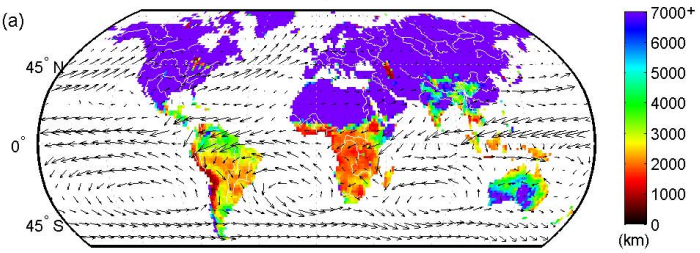

Depletion time $T_{P}$ in January

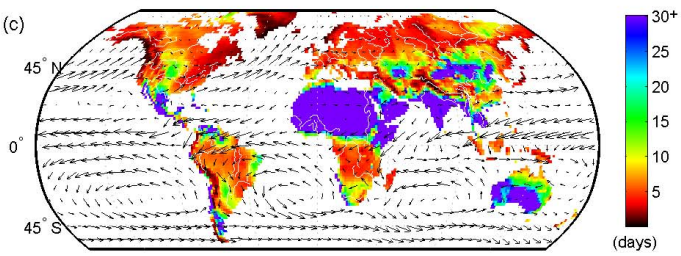

Length scale of evaporation recycling $\lambda_{\sigma}$ in January

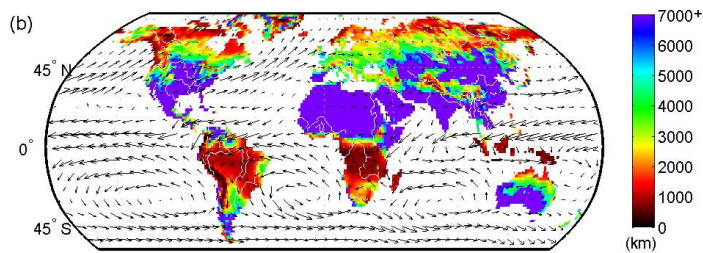

Replenishment time $T_{E}$ in January

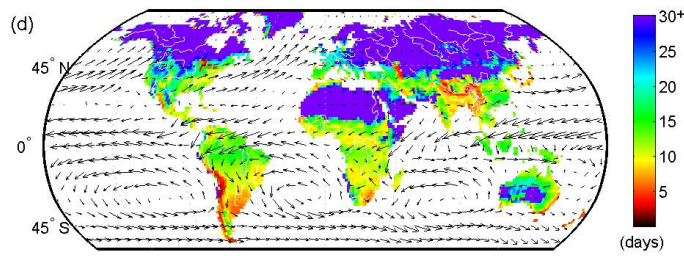

Fig. 7. Average length and time scales of moisture recycling in January (1999-2008). The arrows indicate the horizontal moisture flux field and the other symbols are explained in the text.

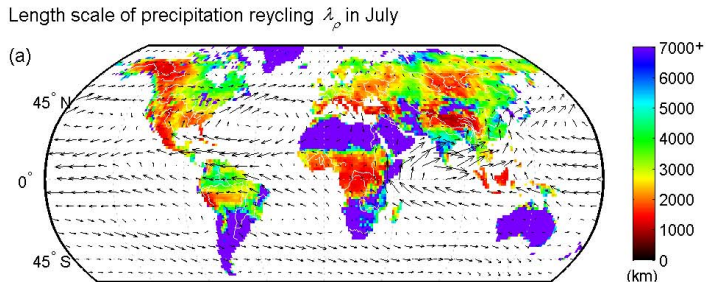

Depletion time $T_{p}$ in July

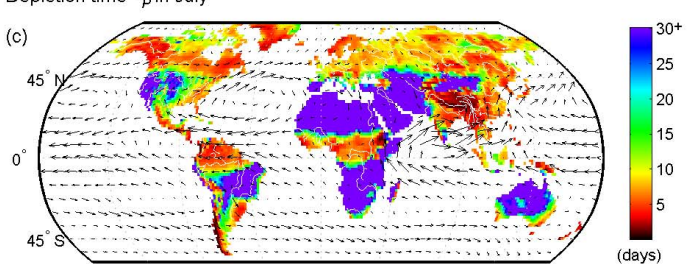

Length scale of evaporation recycling $\lambda_{c}$ in July

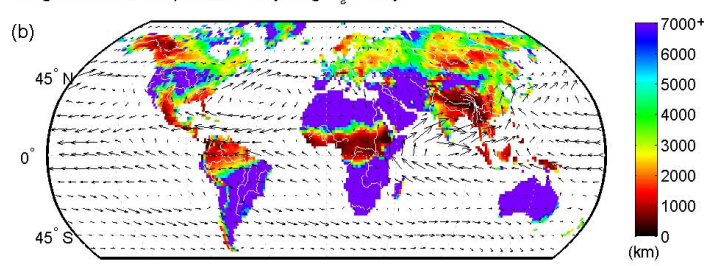

Replenishment time ${ }_{E}$ in July

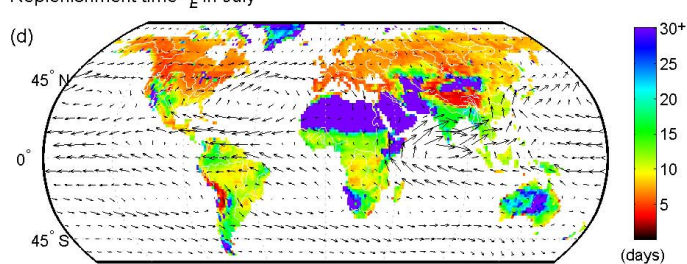

Fig. 8. Average length and time scales of moisture recycling in July (1999-2008). The arrows indicate the horizontal moisture flux field and the other symbols are explained in the text.

\section{Concluding remarks}

We have successfully found a method that can convert scaleand shape-dependent regional moisture recycling ratios into representative, and physical meaningful, length scales of moisture recycling $\left(\lambda_{\rho}\right.$ and $\lambda_{\varepsilon}$, Fig. 5) that do not suffer from scale- or shape-dependence. They allow for a fair comparison between regions and seasons. Moreover, they consider recycling from both a precipitation and an evaporation perspective. For the study of land-atmosphere-interactions these new metrics are therefore more useful than the regional precipitation recycling ratio $\rho_{\mathrm{r}}$ alone.

In addition, we calculated the representative time scales of moisture recycling ( $T_{\mathrm{P}}$ and $T_{\mathrm{E}}$, Fig. 6). Analysis of both the length and times scales yielded the identification of several hotspots of high local moisture recycling, in particular in and around mountainous areas (such as the Rocky Mountains, Andes, Alps, Caucasus and Tibetan Plateau), and in the regions with tropical forest (such as the Amazon, Congo, Indonesia). Moreover, considerable seasonal differences can be observed which overall indicate that local moisture recycling is most significant in summer.

Although this paper provided a global analysis of local moisture recycling, the methodology may also be applied on smaller grids, with more detailed topography, and on periods smaller than years and months. Potentially, it can thus be a useful tool for detailed analysis of local effects of land use and/or change. Whereby the length scale of precipitation recycling $\lambda_{\rho}$ (Fig. 7a) can provide a measure to quantify the effect of deforestation on local climate $\left(\lambda_{\rho}\right.$ a priori will be larger after deforestation). 
Finally, we would like to note that although local recycling may be of minor significance as a rainfall bringing mechanism in some regions, evaporation from those regions can still play an important role in sustaining rainfall elsewhere through continental moisture recycling. As is for example the case with the northern Amazon sustaining rainfall in the Río de la Plata basin (Marengo, 2006; Van der Ent et al., 2010).

Edited by: S. Buehler

\section{References}

Berrisford, P., Dee, D., Fielding, K., Fuentes, M., Kållberg, P. W., Kobayashi, S., and Uppala, S. M.: The ERA-Interim archive, http://www.ecmwf.int/research/era/do/get/era-interim, European Centre for Medium Range Weather Forecasts, Reading, UK, 2009.

Bisselink, B. and Dolman, A. J.: Precipitation recycling: Moisture sources over Europe using ERA-40 data, J. Hydrometeorol., 9, 1073-1083, 2008.

Bosilovich, M. G., Sud, Y., Schubert, S. D., and Walker, G. K.: GEWEX CSE sources of precipitation using GCM water vapor tracers, GEWEX News, 12(1), 6-7, 2002.

Bosilovich, M. G. and Chern, J. D.: Simulation of water sources and precipitation recycling for the MacKenzie, Mississippi, and Amazon River basins, J. Hydrometeorol., 7, 312-329, 2006.

Brubaker, K. L., Entekhabi, D., and Eagleson, P. S.: Estimation of continental precipitation recycling, J. Clim., 6, 1077-1089, 1993.

Burde, G. I. and Zangvil, A.: The estimation of regional precipitation recycling. Part I: Review of recycling models, J. Clim., 14, 2497-2508, 2001.

Burde, G. I.: Bulk recycling models with incomplete vertical mixing. Part I: Conceptual framework and models, J. Clim., 19, 1461-1472, 2006.

Corless, R. M., Gonnet, G. H., Hare, D. E. G., Jeffrey, D. J., and Knuth, D. E.: On the Lambert W function, Adv. Comput. Math., 5, 329-359, 1996.

Dirmeyer, P. A. and Brubaker, K. L.: Characterization of the global hydrologic cycle from a back-trajectory analysis of atmospheric water vapor, J. Hydrometeorol., 8, 20-37, 2007.

Dirmeyer, P. A., Koster, R. D., and Guo, Z. C.: Do global models properly represent the feedback between land and atmosphere?, J. Hydrometeorol., 7, 1177-1198, 2006.

Dirmeyer, P. A., Brubaker, K. L., and DelSole, T.: Import and export of atmospheric water vapor between nations, J. Hydrol., 365, 1122, 2009.

Dominguez, F., Kumar, P., Liang, X. Z., and Ting, M.: Impact of atmospheric moisture storage on precipitation recycling, J. Clim., 19, 1513-1530, 2006.

Eltahir, E. A. B. and Bras, R. L.: Precipitation recycling in the Amazon Basin, Q. J. Roy. Meteorol. Soc., 120, 861-880, 1994.

Eltahir, E. A. B. and Bras, R. L.: Precipitation recycling, Rev. Geophys., 34, 367-378, 1996.

Findell, K. L. and Eltahir, E. A. B.: An analysis of the soil moisturerainfall feedback, based on direct observations from Illinois, Water Resour. Res., 33, 725-735, 1997.
Fitzmaurice, J. A.: A critical Analysis of Bulk Precipitation Recycling Models, Ph.D., Department of Civil and Environmental Engineering, Massachusetts Institute of Technology, Massachusetts, USA, 162 pp., 2007.

Gordon, L. J., Peterson, G. D., and Bennett, E. M.: Agricultural modifications of hydrological flows create ecological surprises, Trends Ecol. Evol., 23, 211-219, 2008.

Koster, R. D., Dirmeyer, P. A., Guo, Z., Bonan, G., Chan, E., Cox, P., Gordon, C. T., Kanae, S., Kowalczyk, E., Lawrence, D., Liu, P., Lu, C. H., Malyshev, S., McAvaney, B., Mitchell, K., Mocko, D., Oki, T., Oleson, K., Pitman, A., Sud, Y. C., Taylor, C. M., Verseghy, D., Vasic, R., Xue, Y., and Yamada, T.: Regions of strong coupling between soil moisture and precipitation, Science, 305, 1138-1140, 2004.

Kunstmann, H. and Jung, G.: Influence of soil-moisture and land use change on precipitation in the Volta Basin of West Africa, Int. J. River Basin Manag., 5, 9-16, 2007.

Liu, Z., Tian, L., Yao, T., and Yu, W.: Seasonal deuterium excess in Nagqu precipitation: Influence of moisture transport and recycling in the middle of Tibetan Plateau, Environ. Geol., 55, 15011506, 2008.

Marengo, J. A.: On the hydrological cycle of the Amazon basin; a historical review and current state-of-the-art, Rev. Bras. Meteorol., 21, 1-19, 2006.

Mohamed, Y. A., van den Hurk, B. J. J. M., Savenije, H. H. G., and Bastiaanssen, W. G. M.: Hydroclimatology of the Nile: results from a regional climate model, Hydrol. Earth Syst. Sci., 9, 263278, doi:10.5194/hess-9-263-2005, 2005.

Nieto, R., Gallego, D., Trigo, R., Ribera, P., and Gimeno, L.: Dynamic identification of moisture sources in the Orinoco basin in Equatorial South America, Hydrolog. Sci. J., 53, 602-617, 2008.

Oki, T., and Kanae, S.: Global hydrological cycles and world water resources, Science, 313, 1068-1072, 2006.

Pielke Sr., R. A., Adegoke, J., Beltrán-Przekurat, A., Hiemstra, C. A., Lin, J., Nair, U. S., Niyogi, D., and Nobis, T. E.: An overview of regional land-use and land-cover impacts on rainfall, Tellus Ser. B-Chem. Phys. Meteorol., 59, 587-601, 2007.

Rockström, J., Falkenmark, M., Karlberg, L., Hoff, H., Rost, S., and Gerten, D.: Future water availability for global food production: the potential of green water for increasing resilience to global change, Water Resour. Res., 45, W00A12, doi:10.1029/2007WR006767, 2009.

Savenije, H. H. G.: New definitions for moisture recycling and the relationship with land-use changes in the Sahel, J. Hydrol., 167, 57-78, 1995 .

Savenije, H. H. G.: The runoff coefficient as the key to moisture recycling, J. Hydrol., 176, 219-225, 1996.

Schär, C., Lüthi, D., Beyerle, U., and Heise, E.: The soilprecipitation feedback: A process study with a regional climate model, J. Clim., 12, 722-741, 1999.

Sodemann, H., Schwierz, C., and Wernli, H.: Interannual variability of Greenland winter precipitation sources: Lagrangian moisture diagnostic and North Atlantic Oscillation influence, J. Geophys. Res., 113, D03107, 2008.

Stohl, A. and James, P.: A Lagrangian analysis of the atmospheric branch of the global water cycle. Part II: Moisture transports between earth's ocean basins and river catchments, J. Hydrometeorol., 6, 961-984, 2005.

Tian, L., Yao, T., Sun, W., Stievenard, M., and Jouzel, J.: Relation- 
ship between $\mathrm{D}$ and ${ }^{18} \mathrm{O}$ in precipitation on north and south of the Tibetan Plateau and moisture recycling, Sci. China Ser. D-Earth Sci., 44, 789-796, 2001.

Trenberth, K. E.: Atmospheric moisture residence times and cycling: Implications for rainfall rates and climate change, Clim. Change, 39, 667-694, 1998.

Trenberth, K. E., Smith, L., Qian, T. T., Dai, A., and Fasullo, J.: Estimates of the global water budget and its annual cycle using observational and model data, J. Hydrometeorol., 8, 758-769, 2007.

Van der Ent, R. J., Savenije, H. H. G., Schaefli, B., and Steele-Dunne, S. C.: Origin and fate of atmospheric moisture over continents, Water Resour. Res., 46, W09525, doi:10.1029/2010WR009127, 2010.
Yoshimura, K., Oki, T., Ohte, N., and Kanae, S.: Colored moisture analysis estimates of variations in 1998 Asian monsoon water sources, J. Meteorol. Soc. Jpn., 82, 1315-1329, 2004.

Yu, W., Yao, T., Tian, L., Ma, Y., Kurita, N., Ichiyanagi, K., Wang, Y., and Sun, W.: Stable isotope variations in precipitation and moisture trajectories on the Western Tibetan Plateau, China, Arct. Antarct. Alp. Res., 39, 688-693, 2007. 